\title{
Kewenangan Notaris Dalam Pembuatan Akta Perjanjian Hibah Atas Tanah
}

\author{
Umi Aliffa1, I Wayan Wiryawan ${ }^{2}$ \\ ${ }^{1}$ Fakultas Hukum Universitas Udayana, E-mail: umialiffa@gmail.com \\ ${ }^{2}$ Fakultas Hukum Universitas Udayana, E-mail: wayan_wiryawan@yahoo.com
}

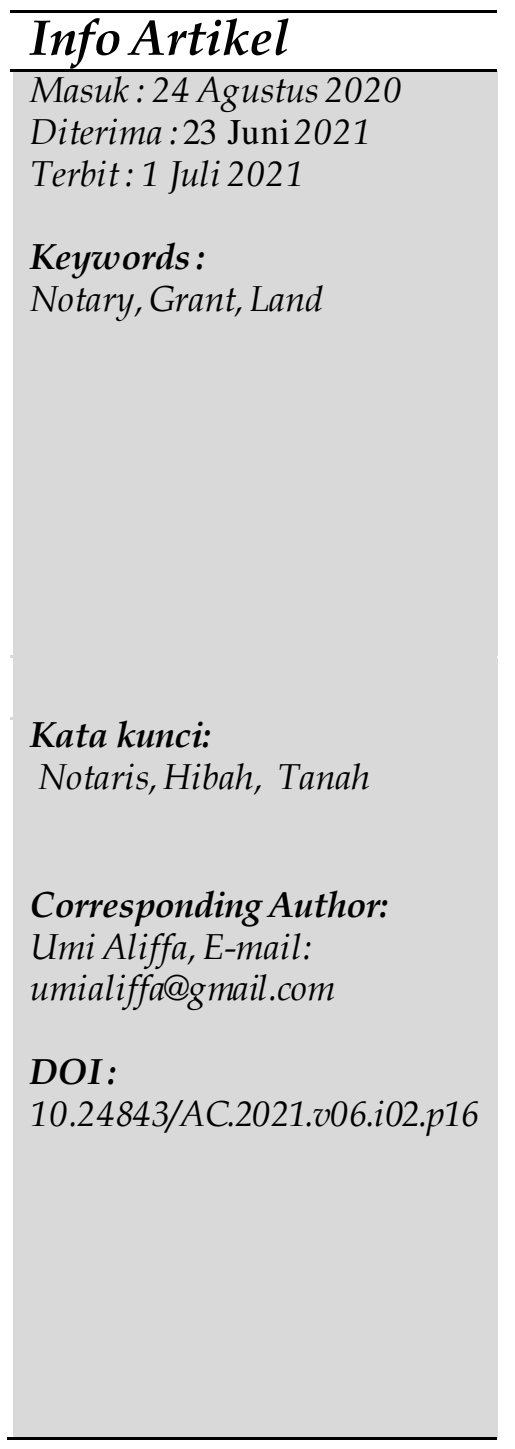

\begin{abstract}
The purpose of this study was to determine and understanding the authority of the Notary in making the Deed of Grant Agreement on land based on the Civil Code and the Authority of the Notary in making the Deed of Grant Agreement on land based on the Act of Notary Position. Thisstudy uses a normative research method with a statutory approach and a library approach. The results of the study that the Civil Code has regulated agreements and regulates grants, based on the Civil Code Notaries have the authority to make a Deed of Grant Agreement on land, namely based on Article 1666, Article 1682 of the Civil Code, while in the Law on Notary Positions the authority of a Notary to make a deed is based on Article 15 paragraphs (1) and (2) of the Law on Notary Positions.
\end{abstract}

\begin{tabular}{l}
\hline Abstrak \\
\hline Tujuan dari penelitian ini adalah untuk memahami dan \\
mengetahui kewenangan-kewengangan Notaris dalam hal \\
pembuatan Akta Perjanjian Hibahatas tanah berdasarkan Kitab \\
Undang-Undang Hukum Perdata dan Kewenangan Notaris \\
dalampembuatan Akta Perjanjian Hibah atas tanah berdasarkan \\
Undang-Undang Jabatan Notaris. Penelitian ini menggunakan \\
metode penelitian normatif dengan pendekatan Perundang- \\
undangandanpendekatankepustakaan. Hasil penelitian bahwa \\
KUHPerdata telah mengatur tentang perjanjian dan mengatur \\
tentang hibah maka berdasarkan KUHPerdata Notaris \\
berwenang membuat Akta Perjanjian Hibah atas tanah yaitu \\
berdasarkan Pasal 1666, Pasal 1682 Kitab Undang-Undang \\
Hukum Perdata, sedangkandi dalam Undang-Undang Jabatan \\
Notaris kewenangan Notaris untuk membuat akta adalah \\
berdasarkan Pasal 15 ayat(1) dan (2) Undang-Undang Jabatan \\
Notaris.
\end{tabular}

\section{Pendahuluan}

Manusia merupakan makhluk sosial ciptaan Tuhan yang sejatinya tidak akan bisa hidup seacara individual tanpa adanya pertolongan dan bantuan dari orang lain.faktanya, banyak individu yang hidup secara individual, hal ini terjadi karena manusia 
mempunyai urusan dan juga kesibukan, dan kegiatan masing-masing, namun manusia akan menjalani kodratnya sebagai mahkluk sosial, yaitu pada kehidupan bermasyarakat, manusia akan membutuhan manusia satu sama lain. Manusia sebagai makhluk sosial akan selalu mempunyai keiinginan dan kebutuhan juga keperluan dalam bermasyarakat untuk melakukan sosialisasi antar sesama. Pada saar menjalin suatu hubungan sesama manusia, masing masing individu pastinya mempunyai kepentingan juga kebutuhan hidup yang berbeda beda. terkadang kepentingankepentingan tersebut tidak sesuai dengan kaidah yang berlaku dan akan timbul suatu persmasalah antara para pihak. Beberapa contoh dari interaksi sosial didalam kehidupan bermasyarakat yaitu peristiwa hibah,dimana pelaksanaanya sudah diatur oleh ketentuan hukum dan juga peraturan yang sedang berlaku.

Salah satu dari bentuk interaksi antar manusia yang dimana perannya sebgai makhluk sosial adalah melakukan hibah. Hibah memiliki arti yaitu pemberian yang dilakukan cuma-cuma atau sebagai hadiah untuk seseorang. Peristiwa hibah dapat juga dijadikan suatu fungsi sosial didalam kehidupan bermasyarakat, apabali jika terjadi permasalah didalam pewarisan tanah nantinya akan dapat diselesaikan melalui cara hibah. Namun, tidak hanya masalah pewarisan tanah, barang bergerak juga termasuk didalamnya. ${ }^{1}$ Dasar seseorang memberikan hibah adalah atas kepercayaannya kepada seseorang untuk menjaga barang miliknya kelak, yang diikat oleh perjanjian.

Hibah merupakan suatu pemberian yang dilakukan oleh seseorang kepada seseorang lainnya pada waktu masih hidup. Pemberian hibah merupakan pemberian suatu harta kekayaan yang memiliki sifat bergerak maupun tidak bergerak, dengan ini yang memberikan hibah dinamakan sebagai pemberi hibah. ${ }^{2}$ Semasa masih hidup seseorang yang telah cakap berbuat hukum dapat melakukan hibah kepada seseorang, dengan memberikan berupa barang yang asalnya adalah kepemilikan pribadi atau sudah atas nama pribadi.

Hibah didalamnya terdapat karakter yang sifatnya sepihak, karena beban kewajiban hanya dibebani oleh pemberi hibah, sedangkan penerima hibah tidak mempunyai kewajiban. Hibah dikatakan dalam bahasa Belanda sebagai schenking, yang merupakan tindakan sepihak oleh seseorang kepada seseorang dengan menyerahkan hartanya dengan cuma-cuma melalui dan berdasarkan perjanjian hibah yang dibuat oleh dan dihadapan Notaris, perjanjian hibah mana dikatakan perjanjian sepihak (unilateral) yang lawannya adalah perjanjian timbal balik (bilateral), dengan perjanjian sepihak ini maka seseorang yang diserahkan harta secara cuma-cuma harus dapat menerima dan bersedia untuk memelihara apa yang telah diberikan oleh seseorang tersebut berdasarkan perjanjian hibah. ${ }^{3}$

1 Mandasari, N. (2018). Cacat Hukum dalam Hibah sebagai Perjanjian Sepihak dan Implikasinya. NOTARIUS, 11(1), 100-114. DOI: https://doi.org/10.14710/nts.v11i1.23128. h. 7 .

${ }^{2}$ Anggreni, N. O., \& Subanda, I. N. (2020). Implementasi Kebijakan Penyaluran Hibah dan Bantuan Sosial Kemasvarakatan di Kabupaten Buleleng. Jurnal Ilmiah MEA (Manajemen, Ekonomi, \& Akuntansi), 4(2), 98-115. h. 2.

${ }^{3}$ Malahayati, M., Abbas, S., \& Dahlan, D. (2019). Kekuatan Hukum Akta Hibah untuk Anak Angkat.Kanun Jurnal Ilmu Hukum, 21(2), 187-208. DOI: https://doi.org/10.24815/kanun.v21i2.11448 . h. 188. 
Penghibahan mulai terjadi ketika anak-anak telah beranjak dewasa atau sudah mulai berdiri dan telah mencapai kesuksesan dalam hidupnya, dengan memiliki segenap harta benda bergerak/tidak bergerak yang akan di investasikan dan dihibahkan kepada seseorang nantinya sepanjang masih hidup. Penyebab terjadinya hibah juga dikarenakan rasa kekhawatiran yang dimiliki ketika kenyataannya bahwa ibu dari anakanak adalah merupakan ibu tiri atau ibu sambung dan juga adanya anak angkat yang tidak termasuk ahli waris. ${ }^{4}$

Hibah dilakukan oleh seseorang yang cakap berbuat hukum dan tidak dipaksa oleh orang lain, harus terjadi murni dari diri sendiri, dalam perbuatan hukum dikatakan sebagai pemindahan hak milik yang harus dilakukan semasa masih hidup. Pemindahan tersebut dilakukan secara cuma-cuma bukan secara jual beli. ${ }^{5}$

Perjanjian antara penghibah dengan penerima hibah dilakukan oleh mereka pada waktu masih hidup dan telah cakap melakukan perbuatan hukum, pelaksanaan pemberian hibah yang dilakukan dengan cara cuma-Cuma. Dimana orang yang nantinya telah diberikan tidak akan bisa diminta lagi, penyerahan tersebut tidak lain adalah untuk keperluan penerima hibah, yang sesuai dengan ketentuan yang dicantumkan pada Pasal 1666 Kitab Undang Undang Hukum Perdata, selanjutnya disingkat KUHPerdata. ${ }^{6}$ Unsur unsur hibah :7

1. Berupa perjanjian sepihak dengan penyerahan harta kekayaan secara cuma-cuma, adalahyang membuat perjanjian hanya pemberi hibah dengan memasukkan harta kekayaan yang akan dihibahkan, harta kekayaan dalam bentuk/berupa barang bergerak/tidak bergerak yang mempunyai nilai nominal.

2. Ada maksud untuk menguntungkan penerima hibah, menguntungkan dalam hal penerimaan obyek hibah yang akan diterima secara cuma-cuma, menerima dengan tidak membayar uang sepeser pun, hanya berkewajiban untuk menjaga obyek hibah.

3. Harta sebagai obyek perjanjian, merupakan harta bergerak atau harta tidak bergerak, seperti halnya tanah dan bangunan, sejumlah uang, mobil ataupun barang bergerak/tidak bergerak lainnya.

4. Yang dihibahkan tidak bisa diambil lagi, apa yang telah diterima berdasarkan perjanjian hibah tersebut tidak bisa diambil lagi, kecuali undang-undang lain mengaturnya.

5. Pelaksanaan semasa masih hidup, hanya bisa dilakukan apabila keduanya masih hidup.

\footnotetext{
4 Fitria, I. N. (2014). Hibah menurut Kompilasi Hukum Ekonomi Syariah dan Kitab Undang-undang Hukum Perdata: Studi perbandingan (Doctoral dissertation, Universitas Islam Negeri Maulana Malik Ibrahim). hal. 88.

${ }^{5}$ Yuvita, Y. (2018). Hibah Orang Tua Kepada Anak Menurut Perspektif Hukum Perdata Dan Hukum Islam Pada Masvarakat Di Kelurahan Betungan Kota Bengkulu. Qiyas: Jurnal Hukum Islam dan Peradilan, 3(1), 63-72. h. 65.

${ }^{6}$ M.Idris Ramulyo, 2004, Perbandingan Hukum Kewarisan Islam Dengan Kewarisan Kitab Undangundang Hukum Perdata, Sinar Grafika, Jakarta, h. 116.

7 Sanjaya, U.H., \&Suprapton, M. Y. (2018). Kedudukan Ahli Waris yang Penerima Hibah dari Orang Tua terhadap Ahli Waris Lainnya pada Proses Pembagian Waris. Jurnal Yuridis, 4(2), 218233. DOI: http://dx.doi.org/10.35586/.v4i2.253. h. 220.
} 
6. Dilaksanakan setelah pemberi hibah meninggal, terlaksana ketika pemberi hibah sudah meninggal.

7. Atas dasar akta Notaris, perjanjian hibah dan turutannya haruslah semuanya berdasarkan akta oleh Notaris.

Sebaliknya, ketentuan yang terdapat pada Pasal 1688 KUH Perdata menyatakan bahwa dalam hibah ternyata bisa diambil lagi, pasal ini bertentangan dengan unsur-unsur diatas, disini diterangkan bahwa hibah dapat diambil lagi, karena :8

a. Syarat resmi yang harus dimasukkan belum terpenuhi, apabila syarat terbentuknya perjanjian tidak terpenuhi, maka apa yang dihibahkan bisa diambil kembali, karena perjanjian tersebut tidak lengkap.

b. Penerima hibah melakukan tindak kejahatan kepada yang memberi hibah, sebelum terlaksananya hibah, penerima hibah melakukan tindak kejahatan kepada pemberi hibah yang akan beresiko batalnya pelaksanaan hibah oleh pemberi hibah.

c. Tidak mau memberikan nafkah ketika yang memberi hibah jatuh miskin, ketika terjadi keadaan jatuh miskin pada si pemberi hibah, dan penerima hibah melakukan penolakan terhadap pemberian bantuan dari si pemberi hibah.

Terdapat pengertian hibah menurut Mazhab Syafi'i yang sejalan dengan dengan Pasal 1688 KUHPerdata, yakni :9

1. Hak terhadap suatu benda yang dimiliki telah diberikan dengan tanpa syarat harus mendapatkan suatu pembalasan yang baik yang diharapkan diberi semasa hidup;

2. Hak milik terhadap suatu barang diberikan kepada orang sebagai penerima tanpa mengharapkan imbalan, dianggap sebagai pemberian semata.

kedua pengertian diatas sejalan dengan bunyi Pasal 1688 KUHPerdata bahwa pemberian suatu benda yang diberikan tanpa syarat harus mendapatkan suatu pembalasan yang baik semasa masih hidup.

Setelah berlakunya Peraturan Pemerintah No. 24 Tahun 1997 tentang Pendaftaran Tanah, akan disingkat menjadi PP No. 24 Th.1997, hibah tanah dilakukan menggunakan akta PPAT, dan didalamnya haruslah dikaitkan dengan obyek yang akan dihibahkan, Peraturan Pemerintah No. 10 Tahun 1961 tentang Pendaftaran Tanah, yang akan menjadi PP No.10 Th.1961, diatur bahwa obyek tanah yang diberikan haruslah diatur di dalam akta hibah, namun apabila obyek yang dihibahkan bukanlah tanah misalnya benda bergerak, maka yang digunakanlah adalah ketentuan di dalam KUHPerdata dalam perjanjian akta hibah dan akta tersebut dibuat dan ditandatangani oleh Notar is. ${ }^{10}$

\footnotetext{
${ }^{8}$ Aditama, P. N. (2017). Tanggung Jawab Pejabat Pembuat Akta Tanah Dalam Memberikan Perlindungan Hukum Bagi Para Pihak Pada Peralihan Hak Atas Tanah Melalui Jual Beli (Doctoral dissertation, Universitas Islam Indonesia). h. 60.

${ }^{9}$ Hoesein, I. (1985, April). Problematika Wasiat Menurut Pandangan Islam. Jakarta: Makalah pada seminar FHUI. h. 10.

${ }^{10}$ Djusfi, A. R., \& Winata, J. (2019). Penyelesaian Sengketa Hibah Menurut Kitab UndangUndang Hukum Perdata. Ius Civile: Refleksi Penegakan Hukum dan Keadilan, 2(2). DOI; 10.35308. h. 55 .
} 
Persekutuan yang terjadi antara dua pihak juga sering disebut dengan perjanjian, dalam bahasa belanda istilah perjanjian dikenal sebagai overeenkomst. ${ }^{11}$ Hak dan kewajiban akan timbul dari para pihak sebagai akibat dari hukum di dalam perjanjian. Adanya perjanjian yang menjabarkan hak dan kewajiban kedua belah pihak dimana nantinya harus terpenuhi. Subekti menyatakan mengenai suatu peristiwa yang melibatkan lebih dari satu orang untuk melakukan suatu hal itu disebut dengan perjanjian ${ }^{12}$, timbulnya hak dan kewajiban dari suatu hal tersebut apabila tidak dilaksanakan maka akan timbul wanprestasi. ${ }^{13}$

KUHPerdata mengatur perjanjian dalam Pasal 1313 serta mengenai syarat perjanjian diatur didalam Pasal 1320 KUHPerdata, bahwa perjanjjian diartikan sebagai perbuatan hukum yang menimbulkan keterikatan dua pihak atau lebih, tanpa paksaan dari pihak lain. ${ }^{14}$ Pemberian hibah tanah dilakukan dengan perjanjian hibah tanah yang dibuat dihadapan Notaris terlebih dahulu karena sertifikat tanah yang akan dihibahkan masih belum selesai pengecekannya di kantor Pertanahan yang berwenang dan apabila proses di kantor pertanahan telah selesai maka akan dilanjutkan dengan akta hibah di hadapan PPAT, dengan ini pelaksanaan hibah bisa dilaksanakan. ${ }^{15}$

Istilah sebutan Notaris berasal yaitu dari kata "notarius" oleh orang romawi dikatakan bahwa notaris mempunyai tugas dan bekerja sebagai penulis, namun disisi lain terdapat pendapat bahwa notaris berasal dari kata "Nota Literia" yang artinya berakarakter dalam berbicara untuk menyatakan suatu perkataan. Pada hakekatnya Notaris merupakan pejabat umum yang mengemban tugas dari kekuasaan umum untuk melayani masyarakat dalam kebutuhan hukum, maka sepanjang kebutuhan masyarakat akan alat bukti maka sepanjang itu jabatan Notaris akan dibutuhkan di tengah masyarakat.

Sejak zaman penjajahan belanda adanya VOC dimana pertama kalinya memperkenalkan jabatan Notaris yakni pada mula abad ke 17 diangkatnya Notaris pertama yaitu Melchior Kerchem,yang menjabat sebagai sekretaris pada College van Schepenen di Jacatra, tepatnya pada tanggal 27 bulan Agustus pada tahun 1620. Melchior Kerchem juga menjabat sebagai Notaris yang pertama di Indonesia. Beliau menjabat sebagai sekretaris College van schepenen, dan setelah beliau diangkat, jumlah angka Notaris akan selalu bertambah sesuai kebutuhan yang dibutuhkan . ${ }^{16}$ Kedudukan Notaris sebagai pejabat Negara sangatlah dibutuhkan di masa sekarang ini, karena masyarakat dalam melakukan perjanjian tidak hanya berdasarkan atas kepercayaan satu

${ }_{11}^{1}$ Suryono, L. J. (2014). Pokok-Pokok Perjanjian Indonesia. h. 43

${ }^{12}$ Hariri, W. M. (2011). Hukumperikatan: dilengkapihukum perikatan dalam Islam. Pustaka Setia. h. 119.

${ }_{13}^{13}$ Malahayati, M., Abbas, S., \& Dahlan, D. (2019). Kekuatan Hukum Akta Hibah untuk Anak Angkat. Kanun Jurnal Ilmu Hukum,21(2), 187-208. DOI: https://doi.org/10.24815/kanun.v21i2.11448 . h. 185.

${ }^{14}$ Gulu, F. A. Aspek Hukum Perjanjian Jual Beli Berdasarkan Kitab Undang-Undang Hukum Perdata, diakses melalui https:/ / media. neliti. com> publications pada hari jum'at 3 Januari 2019.

${ }^{15}$ Arinda, A. (2016). Pelaksanaan Peralihan Hak Milik Atas Tanah Melalui Hibah Untuk Anak Di Bawah Umur (Doctoral dissertation, Sebelas Maret University). h. 44.

16TAUPIQ, Q. (2016). Implementasi Sanksi Pelanggaran Kode Etik Dalam Jabatan Notaris di Kabupaten Bungo (Doctoral dissertation, UNIVERSITAS ANDALAS). h. 1. 
sama lain dan kedua belah pihak, melainkan memerlukan keabsahan dan kekuatan hukum dari perjanjian tersebut. Keabsahan dan kekuatan hukum dari sebuah perjanjian tersebut sangatlah penting untuk para pihak dalam hal pembuatan perjanjian, tdak dipungkiri dimasa yang nantinya akan datang akan timbul wanprestasi atau tidak terlaksananya kewajiban dari salah satu pihak.

Selain kewenangan, Notaris juga mengemban kewajiban sebagai pejabat negara yang patuh pada Undang-Undang Nomor 2 Tahun 2014 tentang Jabatan Notaris, disingkat menjadi UUJN. Dalam UUJN tersebut, Notaris diharapkan dapat memahami dan mengerti segala aturan serta larangan bagi Notaris, dengan memahami dan mengerti maka Notaris tidak akan tersandung masalah dan pelanggaran kode etik Notaris mengenai apa yang telah dilarang oleh UUJN.

Alat bukti diperlukan guna memenuhi dan tersampainya kepastian dan perlindungan hukum agar tertibnya pelaksanaan aturan hukum, dibutuhkan bukti otentik yang dapat menjelaskan adanya perbuatan hukum, perjanjian, peristiwa dan adanya suatu penetapan yang sifatya sangat berkekuatan hukum tetap, dibuat oleh Notaris, hal ini menjadi pertimbangan didalam Undang-Undang Jabatan Notarus, selanjutnya disingkat UUJN. Pertimbangan tersebut telah diputuskan secara rinci di dalam UUJN untuk dipahami dan dimengerti oleh Notaris dalam hal menjalankan jabatannya.

Berdasarkan latar belakang diatas maka ditemukan suatu rumusan masalah yakni bagaimanakah wewenang seorang Notaris dalam hal pembuatan Akta Perjanjian Hibah mengenai tanah dimana hal tersebut didasari dari Kitab Undang Undang Hukum Perdata, dimana seterusnya akan disingkat KUHPerdata, dan bagaimanakah wewenang seorang Notaris dalam pembuatan suatu Akta Perjanjian Hibah mengenai objek tanah yang didasari Undang-Undang tentang Jabatan Notaris, selanjutnya disingkat UUJN. Tujuan penelitian ini yakni untuk dapat menganalisis dan menjawab suatu wewenang yang dimiliki oleh Notaris mengenai pembuatan Akta Perjanjian Hibah atas tanah berdasarkan KUHPerdata serta wewenang yang dimiliki Notaris dalam hal pembuatan Akta Perjanjian Hibah mengenai tanah berdasarkan UUJN.

Sebelumnya terdapat penelitian yang berjudul "Pelaksanaan Peralihan Hak Milik Atas Tanah Melalui Hibah Untuk Anak Di Bawah Umur" karangan Arianda, A Yang membahas mengenai pemberian hibah tanah dilakukan dengan perjanjian hibah tanah yang dibuat PPAT 17 dan penelitian yang berjudul "Kekuatan Hukum Akta Hibah untuk Anak Angkat" karangan Malahayati, M., Abbas, S., \& Dahlan, D yang membahas hak dan kewajiban didalam suatu perjanjian. ${ }^{18}$ Kedua tulisan ini mempunyai beberapa perbedaan kajian dengan tulisan kajian ini karena tulisan ini mencoba untuk mengkaji dan melakukan analisa tentang wewenang Notaris seperti dalam hal membuat Akta Perjanjian Hibah atas tanah berdasarkan KUHPerdata dan juga kewenangan yang dimiliki oleh Notaris saat akan melakukan pembuatan Akta seperti Perjanjian Hibah atas tanah berdasarkan UUJN.

17 Arinda, A. (2016). Pelaksanaan Peralihan Hak Milik Atas Tanah Melalui Hibah Untuk Anak Di Bawah Umur, Op.cit, h. 44.

${ }^{18}$ Malahayati, M., Abbas, S., \& Dahlan, D. (2019). Kekuatan Hukum Akta Hibah untuk Anak Angkat. Op.cit, h. 185. 


\section{Metode Penelitian}

Karya tulis ini ditulis menggunakan jenis metode penelitian hukum normatif19, menggunakan pendekatan perundang-undangan. Pendeketan tersebut digunakan untuk mengetahui dan memahami apakah suatu pasal yang dimaksud tersebut kebenarannya telah sesuai dengan rumusan masalah yang sedang dikaji, agar nantinya bisa melakukan pembahasan yang tepat dan sesuai dengan pendekatan kepustakaan, menggunakan sumber bahan hukum primer dan sumber bahan hukum sekunder. Penggunaan tekhnik dalam pengambilan bahan hukum ialah tekhnik studi dokumen, dan tekhnik analisa bahan hukum dengan cara menganalisis peraturan undang undang dan litelatur yang terkait dalam penelitian karya tulis ini.

\section{Hasil Dan Pembahasan}

\subsection{Kewenangan Notaris dalam pembuatan Akta Perjanjian Hibah atas tanah berdasarkan Kitab Undang-Undang Hukum Perdata}

Hukum perdata adalah sebuah perkumpulan patokan hukum dimana pada dasarnya mengatur mengenai berbagai kepentingan perserorangan dan juga kebutuhan dari kehidupan bermasyarakat. ${ }^{20}$ Termasuk dalam cara dan bentuk penghibahan yang dimana telah ditentukan dimulai dari Pasal 1682 - 1687 Kitab Undang-Undang Hukum Perdata, yang biasanya disingkat KUHPerdata.

KUHPerdata mengatur perjanjian dalam Pasal 1313 serta mengenai syarat perjanjian diatur didalam Pasal 1320 KUHPerdata, bahwa perjanjian diartikan sebagai perbuatan hukum yang menimbulkan keterikatan dua pihak atau lebih, tanpa paksaan dari pihak lain.

Hibah merupakan peristiwa pemberian dimana pemberian ini diberikan oleh seseorang yang disebut sebagai penghibah kepada orang lain ketika penghibah tersebut masih dalam keadaan hidup dan juga dilaksanakan pada saat penghibah masih dalam keaadan hidup.peristiwa Penghibahan dibuat berdasarkan perjanjian hibah. Terhadap anggota keluarga yang tidak menerima pemberian tersebut, tidak pernah mencela, karena pada dasarnya seluruh harta benda kekayaan yang dimiliki oleh seseorang adalah hak seutuhnya bahwa pemilik harta kekayaan tersebut yang bisa dengan leluasa memberikan harta kekayaannya kepada siapa pun. ${ }^{21}$

Pasal 1666 KUHPerdata yang telah mengatur mengenai pengertian hibah yakni terjadinya proses pemberian sesuatu barang hak milik penghibah kepada yang dihibahkan. Jika akan terjadinya suatu proses hibah, maka terjadinya suatu perjanjian yang dilakukan oleh penghibah dan yang dihibahkan dalam suatu perjanjian tertulis dan dilakukan di hadapan pejabat yang berwenang. Hibah atas tanah yang akan

\footnotetext{
${ }^{19}$ Koentjoro, N. (2005). Metode-metode penelitian Masyarakat. Jakarta: PT Gramedia Pustaka Utama. h. 22.

${ }^{20}$ Fitria, I. N. (2014). Hibah menurut Kompilasi Hukum Ekonomi Syariah dan Kitab Undang-undang Hukum Perdata: Studi perbandingan (Doctoral dissertation, Universitas Islam Negeri Maulana Malik Ibrahim).h. 115.

${ }^{21}$ Hindrato, D. M. (2017). Pembatalan akta hibah oleh saudara kandung penerima hibah melalui penetapan pengadilan (studi penetapan Nomor: 581/Pdt. P/2015/PN. SBY) (Doctoral dissertation, UNS (Sebelas Maret University)). h. 80.
} 
dilakukan oleh penghibah kepada yang dihibahkan tetap dilakukan dengan sebuah perjanjian tertulis yang dilakukan oleh dan dihadapan Notaris dan juga PPAT.

Pasal 1671 KUHPerdata mengatur bahwa penghibah membuat janji akan selalu berkuasa terhadap sekumpulan uang yang digunakan atas barang-barang yang dihibahkan, namun apabila penghibah telah meninggal sebelum penggunaan uang tersebut, maka uang beserta barang yang dihibahkan menjadi milik orang yang dihibahkan. Dalam hal ini klausula tersebut akan menjadi wewenang Notaris untuk memasukkan ke dalam perjanjian hibah yang akan menjadi klausula di dalam perjanjian. Hal ini akan dimasukkan apabila obyek tanah yang akan dihibahkan suatu saat nanti akan dijual dan hasil dari penjualan tanah tersebut akan boleh dinikmati oleh pemberi hibah selama pemberi hibah masih hidup.

Pasal 1672 KUHPerdata menyebutkan bahwa penghibah berhak untuk mengambil kembali obyek yang dihibahkan apabila orang yang dihibahkan dan keturunan dari penerima hibah telah meninggal dunia mendahului si penghibah, dengan ketentuan dibuatkan akta perjanjian baru dengan kesepakatan pihak-pihak. Notaris berwenang berdasarkan Pasal 1672 KUHPerdata membuatkan perjanjian baru apabila berdasarkan kejadian penerima hibah dan keturunannya meninggal dunia mendahului pemberi hibah.

Dalam KUHPerdata, sesuai ketentuan yang berlaku dalam Pasal 1683 disebutkan :

“Tiada suatu hibah mengikat si penghibah, atau menerbitkan sesuatu akibat yang bagaimanapun, selain mulai dari penghibahan itu dengan kata-kata yang tegas telah diterima oleh si penerima hibah sendiri atau oleh seseorang yang dengan suatu akta otentik oleh si penerima hibah itu telah dikuasakan untuk menerima penghibahan penghibahan yang telah diberikan kepada si penerima hibah atau akan diberikan kepadanya di kemudian hari. Jika penerimaan tersebut tidak telah dilakukan di dalam surat hibah sendiri, maka itu akan dapat dilakukan di dalam suatu akta otentik terkemudian, yang aslinya harus disimpan, asal yang demikian itu dilakukan di waktu si penghibah masih hidup, dalam hal mana penghibahan, terhadap orang yang belakangan disebut ini, hanya akan berlaku sejak hari penerimaan itu diberitahukan kepadanya".

Bedasarkan penjelasan diatas dinyatakan bahwa peristiwa hibah terjadi jika tidak disertai dengan serah terima barang kepada sang penerima hibah (tunai) haruslah dilakukan penerimaan terlebih dahulu oleh sang penerima hibah supaya terikat dengan sang pelaku hibah. Penerimaan tersebut dilaksanakan dari sang penerima hibah atau dari seorang kuasa di hadapan Notaris. Barang tersebut bergerak sebagaimana dimaksud dalam Pasal 1687, dimana didalam pasal tersebut dikatakan bahwa barang dapat dihibahkan tanpa harus disertai penyerahan secara tunai, namun, peristiwa hibah haruslah dilaksanakan didalam akta, sedangkan penyerahan barangnya akan dilaksanakan setelahnya.

Kewenangan Notaris saat membuatan Akta Perjanjian Hibah berdasarkan KUHPerdata adalah dalam Pasal 1666 KUHPerdata yaitu menegaskan bahwa hibah bisa dilakukan dan Pasal 1671, 1672, 1687 KUHPerdata. Pelaksanaan perjanjian hibah tanah dibuat oleh 
Notaris atas dasar kewenangannya haruslah mengacu pada KUHPerdata dalam merumuskan klausula-klausula di dalam Akta Perjanjian Hibah.

\subsection{Kewenangan Notaris dalam pembuatan Akta Perjanjian Hibah atas tanah berdasarkan Undang-Undang Jabatan Notaris.}

Pada ketentuan Undang Undang Jabatan Notaris Pasal 1 angka 1, selanjutnya disingkat UUJN, menyatakan "Notaris adalah seorang Pejabat Umum yang berwenang untuk membuat akta otentik dan memiliki kewenangan lain yang diatur dalam undangundang ini atau undang-undang lainnya". Istilah dari pejabat umum adalah Openbare Amtbtenaren mempunyai arti yaitu pejabat yang memiliki tugas untuk melayani masyarakat. Seorang notaris yang berperan sebagai pejabat umum mempunyai tugas dalam pembuatan akta otentik guna melayani masyarakat. ${ }^{22}$

Dalan ketentuan yang terdapan pada UUJN, bedasarkan Pasal 15 ayat (1) mengenai kewenangan yang dimiliki oleh Notaris yakni "Notaris mempunyai yang kewenangannya untuk membuat sebuah akta autentik tentang semua perbuatan, perjanjian dan penetapan yang diharuskan oleh undang-undang dan/atau yang dikehendaki oleh yang berkepentingan untuk dituangkan dan dinyatakan di dalam akta autentik, dan dapat menjamin kepastian tanggal pembuatan akta, menyimpan akta, memberikan grosse, salinan dan kutipan akta, sepanjang semuanya itu tidak dilimpahkan atau ditugaskan kepada pejabat lain atau orang lain yang ditetapkan undang-undang". Dalam hal ini atas kehendak undang-undang pembuatan Akta Perjanjian Hibah dapat dibuat oleh Notaris yang turut tunduk terhadap peraturan perundangan yang sedang berlaku. Akta Perjanjian Hibah atas tanah yang dibuatkan oleh Notaris dan juga dibacakan oleh Notaris dihadapan pemberi dan penerima hibah dengan mencantumkan tanda tangan di dalam akta maka Akta Perjanjian Hibah atas tanah tersebut memiliki kepastian hukum mengenai peristiwa hukum yang terjadi dalam akta tersebut.

Selain kewenangan diatas, Pasal 15 ayat (2) UUJN menyebutkan Notaris juga memiliki beberapa kewenangan, yaitu :

a. Melakukan pengesahan tanda-tangan serta memastikan tanggal surat;

b. Membuat pembukuan;

c. Mengkopi asli surat;

d. Mencocokan kopian tersebut ;

e. Memberi nasehat hukum dan konsultasi hukum terkait akta yang dibuat;

f. Membuat dan mengasahkan akta terkait objek tanah ;

g. Membuat dan mengesahkan akta terkait pelaksanaan lelang.

Bedasarkan Pasal 15 ayat (2) pada huruf f UUJN tentang kewenangan yang dimiliki oleh Notaris yang membuat akta terkait dengan pertanahan dapat menyebabkan beberapa penafsiran, yaitu Pasal 15 ayat (2) pada huruf f UUJN memberikan kewenangannya untuk seorang Notaris dalam pembuatan akta yang terkait dengan pertanahan, tetapi, secara tidak tegas juga mengatur tentang batasan batasan kewenangan yang dimiliki

22Adolf, J. J., \& Handoko, W. Eksistensi Wewenang Notaris Dalam Pembuatan Akta Bidang Pertanahan. Notarius, 13(1), 181-192.Doi 10.14710/nts.v13i1.29313. h. 185 
oleh seorang Notaris terhadap kewenangan PPAT, khususnya didalam proses pembuatan akta. ${ }^{23}$ Dalam prakteknya, kewenangan Notaris hanya sebatas membuat akta, khususnya dalam pertanahan kewenangan Notaris sebatas dalam akta ikatan dan perjanjian mengenai tanah dikarenakan faktor bukti kepemilikan atas tanah yang menjadi obyek di dalam akta masih dilakukan kepengurusannya di kantor pertanahan yang berwenang, dan sambil menunggu proses kepengurusannya tersebut kedua belah pihak sudah diikat oleh akta ikatan atau perjanjian yang dibuat oleh Notaris.

Bukti kepemilikan atas tanah yang telah selesai kepengurusannya di kantor pertanahan yang berwenang maka berdasarkan akta ikatan atau perjanjian yang dibuat dan disahkan oleh seorang Notaris. Dalam hal ini khususnya Akta Perjanjian Hibah atas tanah akan dibuatkan Akta Hibah yang dibuat oleh Pejabat Pembuat Akta Tanah (PPAT) dan akan dilakukan pengalihan hak menganai tanah tersebut yang didasari oleh Akta Hibah, dimana akta hibah ini dibuat oleh PPAT.

Berdasarkan ketentuan tertulis dalam UUJN Pasal 15 ayat (1), maka seorang Notaris mempunyai hak dalam pembuatan acta dimana salah satunya adalah Akta Perjanjian Hibah atas tanah, kewenangan Notaris hanya sebatas membuat akta untuk mengikat terlebih dahulu pemberi hibah dan penerima hibah, jika pengurusan tanda bukti hak kepemilikan atas tanah telah selesai maka kewenangan PPAT untuk membuat Akta Hibah agar bisa beralihnya hak kepemilikan atas tanah tersebut.

\section{Kesimpulan}

Kewenangan Notaris dalam pembuatan Akta Perjanjian Hibah berdasarkan KUHPerdata adalah dalam Pasal 1666 KUHPerdata yaitu menegaskan bahwa hibah bisa dilakukan dan Pasal 1671, 1672, 1687 KUHPerdata. Pelaksanaan perjanjian hibah tanah dibuat oleh Notaris atas dasar kewenangannya haruslah mengacu pada KUHPerdata dalam merumuskan klausula-klausula di dalam Akta Perjanjian Hibah. Kewenangan Notaris membuat Akta Perjanjian Hibah atas tanah yaitu berdasarkan UUJN Pasal 15 ayat (1) maka Notaris memiliki kewenangan dalam membuat dan mengesahkan suatu akta dimana salah satunya adalah Akta Perjanjian Hibah atas tanah.

\section{Daftar Pustaka / Daftar Referensi}

$\underline{\text { Buku }}$

Hariri, W. M. (2011). Hukum perikatan: dilengkapi hukum perikatan dalam Islam. Pustaka Setia

M.Idris Ramulyo, 2004, Perbandingan Hukum Kewarisan Islam Dengan Kewarisan Kitab Undang undang Hukum Perdata, Sinar Grafika, Jakarta

Suryono, L. J. (2014). Pokok-Pokok Perjanjian Indonesia

Suparman, E. (1985). Intisari Hukum Waris Indonesia. Armico.

23Sari, I. G. A. D., Wairocana, I. G. N., \& Resen, M. G. S. K. (2017). Kewenangan Notaris dan Ppat dalam Proses Pemberian Hak Guna Bangunan Atas Tanah Hak Milik. Acta Comitas, 3. Doi 2502 -8 960 I e -I SS N : 2502 -7573. h.10. 


\section{Jurnal}

Adolf, J. J., \& Handoko, W. Eksistensi Wewenang Notaris Dalam Pembuatan Akta Bidang Pertanahan. Notarius, 13(1), 181-192. DOI: 10.14710/nts.v13i1.29313

Djusfi, A. R., \& Winata, J. (2019). Penyelesaian Sengketa Hibah Menurut Kitab UndangUndang Hukum Perdata. Ius Civile: Refleksi Penegakan Hukum dan Keadilan, 2(2). DOI; 10.35308

Hoesein, I. (1985, April). Problematika Wasiat Menurut Pandangan Islam. Jakarta: Makalah pada seminar FHUI.

Malahayati, M., Abbas, S., \& Dahlan, D. (2019). Kekuatan Hukum Akta Hibah untuk Anak Angkat. Kanun Jurnal Ilmu Hukum, 21(2), 187-208. DOI: https://doi.org/10.24815/kanun.v21i2.11448

Mandasari, N. (2018). Cacat Hukum dalam Hibah sebagai Perjanjian Sepihak dan Implikasinya. NOTARIUS, 11(1), 100-114.

DOI: https://doi.org/10.14710/nts.v11i1.23128

Sari, I. G. A. D., Wairocana, I. G. N., \& Resen, M. G. S. K. (2017). Kewenangan Notaris dan Ppat dalam Proses Pemberian Hak Guna Bangunan Atas Tanah Hak Milik. Acta Comitas, 3. DOI: $2502-8960$ I e -I SS N : 2502-7573

Sanjaya, U. H., \& Suprapton, M. Y. (2018). Kedudukan Ahli Waris yang Penerima Hibah dari Orang Tua terhadap Ahli Waris Lainnya pada Proses Pembagian Waris. Jumal Yuridis, 4(2), 218-233. DOI: http://dx.doi.org/10.35586/.v4i2.253

Yuvita, Y. (2018). Hibah Orang Tua Kepada Anak Menurut Perspektif Hukum Perdata Dan Hukum Islam Pada Masyarakat Di Kelurahan Betungan Kota Bengkulu. Qiyas: Jurnal Hukum Islam dan Peradilan, 3(1), 63-72.

\section{$\underline{\text { Disertasi }}$}

Aditama, P. N. (2017). Tanggung Jawab Pejabat Pembuat Akta Tanah Dalam Memberikan Perlindungan Hukum Bagi Para Pihak Pada Peralihan Hak Atas Tanah Melalui Jual Beli (Doctoral dissertation, Universitas Islam Indonesia).

Arinda, A. (2016). Pelaksanaan Peralihan Hak Milik Atas Tanah Melalui Hibah Untuk Anak Di Bawah Umur (Doctoral dissertation, Sebelas Maret University).

Fitria, I. N. (2014). Hibah menurut Kompilasi Hukum Ekonomi Syariah dan Kitab Undang-undang Hukum Perdata: Studi perbandingan (Doctoral dissertation, Universitas Islam Negeri Maulana Malik Ibrahim).

Hindrato, D. M. (2017). Pembatalan akta hibah oleh saudara kandung penerima hibah melalui penetapan pengadilan (studi penetapan Nomor: 581/Pdt. P/2015/PN. SBY) (Doctoral dissertation, UNS (Sebelas Maret University)). 


\section{Internet}

Gulu, F. A. Aspek Hukum Perjanjian Jual Beli Berdasarkan Kitab Undang-Undang Hukum Perdata, diakses melalui https://media. neliti. com> publications pada hari jum'at 3 Januari 2019

\section{Peraturan Undang-Undang}

Kitab Undang-Undang Hukum Perdata (burgerlijk wetboek), dengan tambahan undangundang pokok agrarian dan undang-undang perkawinan, diterjemahkan oleh R.Subekti dan R. Tjitrosudibio, 2008, Cetakan 39, Pradnya Paramita.

Undang-Undang Negara RI, Undang-Undang No. 2 Th. 2014 tentang perubahan Undang-Undang Negara RI, Undang-Undang No. 30 Th. 2004 tentang Jabatan Notaris (Lembaran Negara RI Th. 2014 No. 3 perubahan atas Lembaran Negara RI Th. 2004 No. 117 Tambahan Lembaran Negara 4432).

Peraturan Pemerintah RI, Peraturan Pemerintah No. 24 Th, 1997 tentang Pendaftaran Tanah (Lembaran Negara RI Th. 1997 No. 59 Tambahan Lembaran Negara RI No. 3696). 